\title{
HUBUNGAN DUKUNGAN KELUARGA DAN MOTIVASI DENGAN MINAT LANSIA TERHADAP POSBINDU
}

\author{
Jeane Sumendap ${ }^{1}$,Sefti Rompas ${ }^{2}$, Valen Simak ${ }^{2}$ \\ 1. Mahasiswa Program Studi Ilmu Keperawatan, Fakultas Kedokteran, \\ Universitas Sam Ratulangi, Indonesia \\ 2. Program Studi Ilmu Keperawatan Fakultas Kedokteran \\ Universitas Sam Ratulangi, Indonesia \\ Email: jeanesumendap2694@yahoo.com.
}

\begin{abstract}
Family support is very much needed in the use of posyandu for the elderly, because with motivation and family assistance, of course the elderly will find it easier to utilize the services provided by the elderly. The purpose of this study was to determine the relationship of family support and motivation with the interests of the elderly towards Posbindu. The method used in this study is a cross sectional study design with 88 samples of elderly people in Tumaluntung Village. Data collection used 2 questionnaires. They were Family Support and Motivation questionnaire. This study used a chi square test with $\alpha$ value $<0.05$. The results showed there was a relationship between family support and motivation and the interest of the elderly towards posbindu in Tumaluntung Village, with the value of family support $p=0.05$ while the value of motivation $p=0.01$. The conclusion of this study there was a relationship between family support and motivation with the interest of the elderly towards posbindu in Tumaluntung Village, Tareran District. Suggestions for health services can be used as input and information to improve services and take proactive actions such as counseling and for future researchers to increase the number of respondents and increase research variables.
\end{abstract}

Keywords: Family Support, Motivation, Elderly Interest

Abstrak: Dukungan keluarga sangat dibutuhkan dalam penggunaan posyandu untuk lansia, karena dengan motivasi dan bantuan keluarga, tentu lansia akan lebih mudah memanfaatkan layanan yang diberikan oleh lansia. Tujuan dari penelitian ini adalah untuk mengetahui hubungan dukungan dan motivasi keluarga dengan minat lansia terhadap Posbindu. Metode yang digunakan dalam penelitian ini adalah desain penelitian cross sectional dengan 88 sampel lansia di Desa Tumaluntung. Pengumpulan data menggunakan 2 kuesioner. Mereka adalah kuesioner Dukungan Keluarga dan Motivasi. Penelitian ini menggunakan uji chi square dengan nilai $\alpha<0,05$. Hasil penelitian menunjukkan ada hubungan antara dukungan dan motivasi keluarga dengan minat lansia terhadap posbindu di Desa Tumaluntung, dengan nilai dukungan keluarga $p=0,05$ sedangkan nilai motivasi $p$ $=0,01$. Kesimpulan dari penelitian ini ada hubungan antara dukungan keluarga dan motivasi dengan minat lansia terhadap posbindu di Desa Tumaluntung, Kecamatan Tareran. Saran untuk layanan kesehatan dapat digunakan sebagai input dan informasi untuk meningkatkan layanan dan mengambil tindakan proaktif seperti konseling dan bagi peneliti di masa depan untuk meningkatkan jumlah responden dan meningkatkan variabel penelitian.

Kata kunci: Dukungan Keluarga, Motivasi, Minat Lansia

\section{PENDAHULUAN}

Masyarakat Indonesia khususnya lanjut usia mengalami barbagai gejala akibat terjadinya penurunan fungsi biologis, psikologis, sosial dan ekonomi. Perubahan tersebut memberikan dampak pada kesehatan lanjut usia. Terjadinya proses menua di kehidupan manusia merupakan hal wajar yang dialami semua orang yang dikaruniai umur panjang. Perkembangan kehidupan lanjut usia yang diharapkan mencakup penyesuaian terhadap penurunan kekuatan dan kesehatan fisik, serta dapat melakukan aktivitas sehari-hari (Tamher \& Noorkasiani, 2009).Salah satu upaya pemerintah dalam mendukung kesehatan masyarakat telah diatur dalam Undang-Undang Kesehatan No. 36 Tahun 2009 dimana upaya untuk meningkatkan 
dan memelihara kesehatan masyarakat termasuk lanjut usia dilaksanakan berdasarkan prinsip non diskriminatif, partisipatif dan berkelanjutan. Setiap upaya untuk meningkatkan derajat kesehatan masyarakat merupakan investasi bagi pembangunan negara. Pemerintah wajib menjamin ketersediaan pelayanan kesehatan memfasilitasi kelompok lanjut usia untuk tetap dapat hidup mandiri dan produktif secara social dan ekonomi, oleh karena itu diperlukan pelayanan kesehatan terhadap lansia dengan membentuk Pos Pelayanan Terpadu usia lanjut/Posbindu lansia (Kemenkes, 2010).

Dukungan yang dapat diberikan oleh keluarga yaitu dukungan informasi: mencakup pemberian nasehat, usul, saran, petunjuk- petunjuk dan pemberian informasi. Dukugan penilaian: mencakup bimbingan umpan balik dan menengahi pemecahan masalah, memberikan support, perhatian. Dukungan instrumental: mencakup sebuah pertolongan praktis dan konkrit, diantaranya kesehatan penderita dalam hal kebutuhan makan dan minum, istrahat yang cukup. Dukungan emosional: mencakup dukungan yang diwujudkan dalam bentuk afeksi, adanya kepercayaan, perhatian, mendengarkan dan didengarkan. Dukungan keluarga menumbuhkan rasa percaya diri dan dapat mengembangkan kecenderungannya dalam hal-hal positif, sehingga lansia akan nyaman dan lebih tenang (Kresnawati \& Kartinah,2010). Motivasi intrinsik yaitu motivasi yang muncul dari dalam diri individu tersebut. Motivasi intrinsik muncul karena adanya suatu kebutuhan. Kebutuhan menunjukkan adanya kekurangan yang dapat dikatakan bahwa dalam diri seseorang ada kekuatan yang mengarah kepada tindakannya (Koemono, 2005 dikutip dalam Suliastiningsih, 2016). Motivasi ekstrinsik yaitu motivasi karena adanya rangsangan atau pengaruh dari luar. Rangsangan tersebut dari dukungan keluarga, teman bergaul maupun lingkungan.

Posbindu lansia adalah pos pelayanan terpadu untuk masyarakat usia lanjut di suatu wilayah tertentu, yang sudah disepakati dan digerakkan oleh masyarakat dimana mereka bisa mendapatkan pelayanan kesehatan dan merupakan kebijakan pemerintah untuk pengembangan pelayanan kesehatan bagi lansia yang penyelenggaraannya melalui program puskesmas dengan melibatkan peran serta lansia, keluarga, tokoh masyarakat, dan organisasi sosial (Kemenkes, 2010).

Berdasarkan studi pendahuluan yang telah dilakukanolehpeneliti pada tahun2019didapatkandatabahwajumlahlans iayangterdaftardi Posbindu di Desa Tumaluntung pada bulan Agustus 2019sebanyak 155 lansia. Sampel penelitian ini yaitu lansia yang berusia 60 tahun keatas dan lansia yang beresiko tinggi yang berusia 70 tahun ke atas. Posbindu dilaksanakan 1 bulan sekali dan dilakukan oleh petugas puskesmas dan dibantu oleh Tim Penggerak PKK. Jumlah lansia yang berkunjung ke posbindu pada bulan November sebanyak 43 lansia. Dari hasil wawancara peneliti kepada 13 lansia menggunakan kuesioner didapatkan data ada 8 lansia yang berminat ke posbindu karena mereka rutin untuk memeriksakan kesehatan mereka. Ada yang mengatakan sakit itu mahal, dan dari ke 8 lansia tersebut didapatkan beberapa penyakit seperti Diabetes, Hipertensi dan batuk yang paling dominan itu penyakit hipertensi. Yang tidak berminat ada 5 lansia dengan alasan sibuk dengan pekerjaan di kebun, jarak rumah ke posbindu jauh.

\section{METODE PENELITIAN}

Desain ini menggunakan penelitian deskriptif kuantitatif dengan pendekatan cross sectionalPenelitian telah dilakukan di 
desa Tumaluntung Kecamatan TareranWilayah kerja Puskesmas Tareran Penelitian telah dilaksanakan pada bulan Desember 2019. Populasi adalah keseluruhan subjek penelitian (Nursalam, 2009). Populasi pada penelitian ini berjumlah 99 lansia yang berada di desa Tumaluntung Kecamatan Tareran.Sampel pada penelitian ini adalah lansia yang ada di desa Tumaluntung Kecamatan Tareran. Cara pengumpulan sampel yang digunakan yaitu Proportionate stratified random sampling digunakan karena telah diketahui jumlah populasi dari tempat yang akan dijadikan tempat penelitian

Instrument yang digunakan dalam penelitian adalah kuesioner untuk mengukur motivasi terdiri dari 4 pertanyaan, kuesioner dukungan keluarga terdiridari7pertanyaan.Kuesionerinimengg unakanskalalikertyaitu selalu, sering, kadang-kadang, tidak pernah yang dinilai dengan skor 4 jika menjawab selalu, skor 3 jika menjawab sering, skor 2 jika menjawab kadang-kadang dan skor 1 jika menjawab tidak pernah. Sedangkan tingkat Pendidikan terdapat didata demografi.Penelitian ini akan menyajikan analisa data univariat setiap variabel dengan menggunakan distribusi frekuensi dan presentasi, analisa bivariat untuk mengetahui hubungan dari variabel dependen dan independen dengan menggunakan uji chi square.

\section{ETIKA PENELITIAN}

Penelitian ini dilaksanakan dengan mengikuti prinsip etik penelitian, kerahasiaan responden, telah menyelesaikan penelitian dengan no surat 01/01/SKSP/05.13.2004/I-202

\section{HASIL DAN PEMBAHASAN}

\section{Karakteristik Responden Berdasarkan Data Demografi}

Tabel 1 Distribusi responden berdasarkan data demografi

\begin{tabular}{ccc}
\hline Umur & $\mathrm{n}$ & $\%$ \\
\hline 60-70 Tahun & 81 & $92.0 \%$ \\
$>$ 70 Tahun & 7 & $8.0 \%$ \\
\hline Total & 88 & $100 \%$ \\
\hline Jenis Kelamin & $\mathrm{n}$ & $\%$ \\
\hline Laki-Laki & 52 & $59.1 \%$ \\
Perempuan & 36 & $40.9 \%$ \\
\hline Total & 88 & $100 \%$ \\
\hline Pendidikan & $\mathrm{n}$ & $\%$ \\
\hline Tidak Sekolah & 52 & $59.1 \%$ \\
SD & 36 & $40.9 \%$ \\
\hline Total & 88 & $100 \%$
\end{tabular}

Berdasarkan tabel diatas menunjukan distribusi responden terbanyak berumur 60-70 tahun yaitu 81 orang $(92.0 \%)$, sedangkan jumlah responden paling sedikit berumur 70 tahun keatas yaitu 7 orang $(8,0 \%)$, distribusi responden berdasarkan jenis kelamin laki-laki sebanyak 52 orang (59.1\%), sedangkan perempuan hanya 36 orang $(40.9 \%)$, dan distribusi responden berdasarkan tingkat pendidikan yang tidak sekolah sebanyak 52 orang $(59.1 \%)$, sedangkan tingkat pendidikan SD sebanyak 36 orang (40.9 $\%)$. 


\section{Analisis Bivariat}

Tabel 7 Analisis Hubungan Dukungan Keluarga dan Motivasi Dengan Minat Lansia Terhadap Posbindu Di Desa Tumaluntung.

\begin{tabular}{ccccccccc}
\hline $\begin{array}{c}\text { Variabel } \\
\text { Independent }\end{array}$ & \multicolumn{9}{c}{ Minat Lansia } & & & \\
\cline { 2 - 5 } & Aktiv & $\%$ & $\begin{array}{c}\text { Tidak } \\
\text { Aktiv }\end{array}$ & $\%$ & Total & $\%$ & OR & $P$ \\
\hline $\begin{array}{c}\text { Dukungan } \\
\text { Keluarga }\end{array}$ & $\mathrm{n}$ & $\%$ & $\mathrm{n}$ & $\%$ & & & & \\
Baik & 39 & 67.2 & 19 & 32.8 & 58 & 100 & & \\
Kurang & 10 & 33.3 & 20 & 66.7 & 30 & 100 & & 0.05 \\
\hline Total & 49 & & 39 & & 88 & 100 & & \\
\hline Motivasi & & & & & & & & \\
Baik & 41 & 65.1 & 22 & 34.9 & 63 & 100 & & \\
Kurang & 8 & 32.0 & 17 & 68.0 & 25 & 100 & & 0.01 \\
\hline Total & 49 & & 39 & & 88 & 100 & & \\
\hline
\end{tabular}

Berdasarkan tabel diatas, hasil uji hipotesis dengan menggunakan uji chisquare yaitu menunjukkan bahwaresponden yang mendapatkan dukungan keluarga baik mengenai minat lansia berjumlah $58(65.9 \%)$ responden yang terbagi atas $39(67.2 \%)$ responden yang aktif dalam kegiatan posbindu dan 19 (32.8\%) responden yang tidak aktif dalam kegiatan posbindu. Sedangkan responden yang motivasi baik mengenai minat lansia berjumlah $63(71.6 \%)$ yang terbagi atas $41(65.1 \%)$ responden aktif dalam kegiatan posbindu dan $22(34.9 \%)$ responden yang tidak aktif dalam kegiatan posbindu.

Berdasarkan uji statistik menunjukkan dari 88 responden yang terbagi dalam dukungan keluarga dan motivasi diperoleh nilai dari dukungan keluarga $\mathrm{p}$ $=0.05$, sedangkan nilai dari motivasi $\mathrm{p}=$ 0.01. Sehingga hasil penelitian ini menunjukan bahwa terdapat hubungan yang signifikan antara dukungan keluarga dan motivasi dengan minat lansia terhadap posbindu di desa Tumaluntung Kecamatan Tareran maka Ho ditolak. Dan dari hasil analisis diperoleh nilai OR dari Dukungan Keluarga OR $=4.1$ yang artinya responden yang mempunyai dukungan keluarga baik akan berpeluang 4.1 kali lebih aktiv dalam minat berkunjung ke posbindu, dan nilai OR dari Motivasi OR $=3.9$ yang artinya responden yang mempunyai motivasi baik akan berpeluang 3.9 kali lebih aktiv dalam minat berkunjung ke posbindu.

Dukungan keluarga sangat dibutuhkan dalam memanfaatkan posyandu lansia, sebab dengan bantuan keluarga tentunya lansia akan lebih mudah dalam memanfaatkan pelayanan kesehatan lansia yang telah disediakan, keluarga bisa menjadi motivator bagi lansia apabila selalu menyediakan diri untuk mendampingi atau mengantar lansia ke 
posyandu, mengingatkan lansia jika lansia lupa jadwal posyandu dan berusaha membantu mengatasi segala masalah bersama lansia (Faiza, dkk, 2012 dalam Suryana, Amareta, \& Andrianto, 2016). Dukungan positif dari keluarga menjadi dorongan semangat bagi lansia (Permenkes, 2015). Dukungan merupakan suatu upaya yang diberikan ke orang lain, baik moril maupun materil. Dukungan yang diberikan bisa dari keluarga atau teman sejawat, tetapi dukungan keluarga merupakan dukungan yang paling efektif dilakukan, karena keluarga merupakan orang terdekat yang berada disamping individu dalam melakukan aktivitas sehari-hari. Dukungan keluarga yang dapat diberikan yaitu berupa dukungan informasi seperti pertanyaan yang terdapat pada lembar kuesioner apakah keluarga lansia

Berdasarkan hasil penelitian yang dilakukan di desa Tumaluntung didapatkan ada hubungan dukungan keluarga dan motivasi dengan minat lansia terhadap posbindu.Penelitian ini tidak sejalan dengan penelitian yang dilakukan oleh Victoria, D \& G (2015) yang mengatakan bahwa dukungan keluarga merupakan variabel yang paling dominan terhadap pemanfaatan posyandu lansia. Hal ini berarti keluarga memberikan dukungan bagi lansia untuk aktif dikegiatan Posyandu lansia, keluarga juga selalu memperhatikan kebutuhan lansia, mau medengar keluhan lansia dan memberikan bantuan untuk aktifitas lansia sehari-hari. Penelitian yang dilakukan oleh Jumratun (2018) menunjukkan bahwa tidak ada hubungan dukungan keluarga dengan partisipasi lansia pada posyandu lansia karenadidapatkan lansia yang memiliki dukungan keluarga baik tetapi tidak aktif berpartisipasi pada posyandu lansia yaitu karena tidak ada keinginan dari diri lansia memberikan informasi yang berhubungan dengan posyandu lansia.

Dukungan penilaian berupa setuju dengan kegiatan yang ada di posyandu seperti penyuluhan kesehatan, penimbangan berat badan, tinggi badan dan pengukuran tekanan darah, dukungan instrumental, dukungan emosional. Hal ini sejalan dengan penelitian yang dilakukan oleh (Hastuti, Setyo, \& Sudiana, 2015). Dukungan keluarga yang dapat diberikan yaitu berupa dukungan informasi mencakup pemberian nasehat, usulan, saran dan pemberian informasi. Dukungan penilaian mencakup bimbingan umpan balik, membimbing dan menengahi masalah dan memberikan support. Dukungan instrumental mencakup kesehatan. Dukungan emosional mencakup kepercayaan dan perhatian (Kresnawati \& Kartinah, 2010).

tersebut untuk berpartisipasi pada posyandu lansia.

Motivasi tidak pernah terpisahkan dari tiga unsur yaitu kebutuhan, dorongan dan tujuan. Kebutuhan datang karena adanya sesuatu yang tidak terpenuhi, sementara dorongan merupakan suatu petunjuk untuk memenuhi kebutuhan, dan tujuan itu sendiri merupakan hasil akhir dari suatu motivasi (Nursalam, 2001). Secara umum karena adanya kekuatan dorongan yang menggerakkan kita untuk berprilaku tertentu. Oleh karena itu, dalam mempelajari motivasi kita akan berhubungan dengan hasrat, keinginan, dorongan, dan tujuan (Notoadmodjo, 2007).Penelitian yang dilakukan oleh Jumratun (2018) menunjukkan bahwa tidak ada hubungan motivasi dengan partisipasi lansia pada posyandu lansia. Motivasi timbul berupa adanya dorongan dari dalam yang mengarahkan seseorang pada sesuatu. Motivasi juga dapat dipengaruhi dari luar misalnya lingkungan yang mendukung (Rahmah, 2016). Kurangnya pengetahuan akan mengakibatkan dampak yang kurang 
baik dalam pemeliharaan kesehatannya. Pengetahuan lansia mengenai manfaat posyandu ini dapat bersumber dari pengalaman dalam aktivitas sebelumnya. Melalui kegiatan posyandu, lansia akan mendapatkan penyuluhan tentang bagaimana cara hidup sehat dengan segala keterbatasan atau masalah kesehatan yang melekat pada mereka. Pengalaman ini, akan membuat pengetahuan lansia semakin meningkat, kemudian membentuk sikap dan akhirnya mendorong minat atau motivasi mereka untuk selalu mengikuti kegiatan posyandu lansia (Sulaiman, 2016). Lansia yang memiliki motivasi baik dan tidak aktif berpartisipasi pada posyandu lansia yaitu sebagian lansia ke posyandu lansia atas kemauan sendri bukan paksaan dari keluarga atau orang disekitarnya serta adanya kesadaran dari dalam diri lansia sendiri untuk selalu sehat.

Lanjut usia adalah seseorang yang telah mencapai usia 60 tahun keatas. Makin bertambah usia, makin besar kemungkinan seseorang mengalami permasalahan fisik, jiwa, spiritual, ekonomi dan sosial. Permasalahan yang sangat mendasar pada lanjut usia adalah masalah kesehatan akibat proses degeneratif (Kemenkes, 2016). Menjadi lansia adalah proses yang alami dan tidak dapat dihindari. Semakin bertambahnya usia, fungsi tubuh juga mengalami kemunduran, sehingga lansia lebih mudah terganggu kesehatannya,baikfisikmaupunkesehatanj iwa(Sofia\&Gusti, 2017). Posbindu lansia adalah pos pelayanan terpadu untuk masyarakat usia lanjut di suatu wilayah tertentu, yang sudah disepakati dan digerakan oleh masyarakat dimana mereka bisa mendapatkan pelayanan kesehatan dan merupakan kebijakan pemerintah untuk pengembangan pelayanan kesehatan bagi lansia yang penyelenggaraanya melalui program puskesmas dengan melibatkan peran serta lansia, keluarga, tokoh masyarakat, dan organisasi social (Kemenkes, 2010).

\section{SIMPULAN}

Berdasarkan hasil penelitian yang telah dilakukan di Desa Tumaluntung terdapat hubungan yang signifikan antara dukungan keluarga dan motivasi dengan minat lansia terhadap posbindu, Dukungan keluarga di Desa Tumaluntung Kecamatan Tareran menunjukan sebagian besar mendapakan dukungan keluarga yang baik, Motivasi lansia di Desa Tumaluntung Kecamatan Tareran pada umumnya mempunyai motivasi yang baik.Bagi Pelayanan dapat dijadikan bahan masukan serta informasi demi meningkatkan pelayanan dan melakukan tindakan yang proaktif seperti penyuluhan, Bagi Penelitian selanjutnya dapat meneliti faktor-faktor lain yang berhubungan dengan dukungan keluarga dan motivasi dengan minat terhadap posbindu.

\section{DAFTAR PUSTAKA}

Jumratun T. N. (2018). Faktor-Faktor Yang Berhubungan Dengan Partisipasi Lansia Pada Posyandu Lansia di Puskesmas Kassi-Kassi Kota Makasar. Universitas Hasanuddin Makasar. Skripsi

Kemenkes. (2010). Pedoman Pembinaan Kesehatan Lanjut Usia Bagi Petugas Kesehatan. Jakarta: Direktorat Bina Kesehatan Komunitas.

Kemenkes. (2011) Pedoman Umum Pengelolaan Posyandu. Jakarta: Kementerian Kesehatan RI bekerja sama dengan Kelompo Kerja Operasional (POKJANALPOSYANDU)

Kresnawati, I., \& Kartinah. (2010). 
Hubungan Dukungan Keluarga dengan Keaktifan Lansia (Lanjut Usia) dalam Mengikuti Kegiatan di Posyandu Lansia Desa Gonilan Kecamatan Kartasura. Skripsi, 144.

Notoatmodjo, S. (2012). Metodologi Penelitian Kesehatan dan Pendidikan danPerilaku Kesehatan. Jakarta: Rhineka Cipta.

Suryana, A. L., Amareta, D. I., \& Andrianto, A. (2016). Hubungan Eksesibilitas, Dukungan Keluarga dan Status Gizi Lansia dengan Pemanfaatan Posyandu Lansia. Journal Kesehatan Vol. 4 No. 3, 59.

Suliastiningsih. (2016). Hubungan Motivasi dengan Frekuensi Kunjungan ke Posyandu Laraslestari II Pada Lansia di Dusun Karang Tengah Sleman Yogyakarta. Skripsi, 5,6.

Sumirat, W. (2011). Pengaruh Promosi Kesehatan Tentang Posyandu Lansia Terhadap Keaktifan Lansia di Posyandu Lansia. AKP, 45

Sunaryo, Wijayanti, R., Kuhu, M. M., Sumedi, T., Widayanti, E. D., Sukrillah, U. A., et al. (2015). Asuhan Keperawatan Gerontik. Yogyakarta: CV. Andi Offset.
Permenkes. (2015). Penyelenggaraan Pelayanan Kesehatan Usia Lanjut di Pusat Kesehatan Masyarakat. Jakarta: Kementerian Kesehatan RI.

Tamher, S., \& Noorkasiani. (2009). Kesehatan Usia Lanjut dengan Pendekatan Asuhan Keperawatan. Jakarta: Salemba Medika 